\title{
The impact of cloud computing applications on improving EFL critical reading skills of secondary school students
}

\author{
Shaimaa yusef muhammed elhadi
}

\begin{abstract}
The present study aimed at investigating the impact of cloud computing applications on improving EFL critical reading skills of secondary school students. The targeted critical reading sub- skills were (Distinguishing cause and effect relationship, Interpreting the ideas and information implicitly stated in the text, Recognizing the main ideas, Differentiating between facts and opinions, Recognizing author's bias, Differentiating relevant and irrelevant information, Recognizing author's purpose, Inferring the antecedent of the sentence) .

The participants of the study were twenty- first year secondary students at Temai Al-amdid secondary school, Dakahleiia Governorate. They were divided into two groups: The experimental group was trained according to the proposed training program via cloud computing. The control group was trained according to the traditional way of teaching critical reading skills. The experimental treatment was conducted during the second semester of the academic year 2017/2018.The study adopted the quasi experimental design using a pre-post design with two groups: one experimental and one control to measure the effectiveness of using cloud computing in improving critical reading skills of first year secondary stage students. Two instruments were designed and used by the researcher: critical reading skills questionnaire and a pre- post critical reading test.Results indicated that cloud computing applications helped participants improve their EFL critical reading skills and enhance their attitude towards critical reading.
\end{abstract}

Key words: Cloud Computing Applications and EFL Critical Reading Skills .

\section{Introduction:}

Reading is a complex process and not a straightforward process of just decoding words. It is a type of problem solving in which the reader tries to make sense of a text not just from the words and sentences on the page but also from the ideas, memoires, and knowledge evoked by those words and sentences (College of the Canyons, 2012). Critical reading is the use of those cognitive skills and strategies that increase the probability of a desirable outcome.

Critical reading is a rigorous process. It demands active engagement with the text; it can make reading more satisfying and productive and thus help in using difficult material with more confidence.

In critical reading, not all the students could get a sense of what the text is about or how it is organized 
before reading it closely. Most of the students don't have any experience, background or feedback about the text. They could not recognize the difference between the events of the text and could not make questions and discussion about the text. Actually, most of students are passive not active in reading comprehension in general and in critical reading in particular (Kathleen \& Nikki 2016).

The significance of critical reading is summarized by Pirozzi (2003) as: it can help a reader to evaluate textbook material, to uncover motivations and assess arguments, to consider options, products, advertisements and commercials, and to judge policies and programs offered by the various levels of government. (p. 197).

Nowadays, Millions of people want to improve their command of English. They can learn English through formal teaching, travel, study abroad and through the media and the internet. The worldwide need for English has established a growing desire for effective language teaching and language teaching materials and resources. Learners of English need to have a full command of English to a high level of accuracy and fluency. Hence, the need for an effective teaching methodology is increasing.

The use of emerging technology in universities to support teaching and learning has clearly changed the way education is being conducted in many Nations. Educational institutions are able to collaborate, network, share resources, and increase enrolment because of technology. It is common to see many online certificate and degree programs being offered in many universities around the world. Educational institutions throughout the World have become highly dependent on technology for teaching, learning and for conducting research. They continue to seek opportunities to rationalize the way they manage their resources. These opportunities have become even better with the introduction of Cloud Computing program. The potential and efficiency of using Cloud computing program in higher education has been recognized by many universities in the developed countries .

The Cloud computing program relies on a number of existing technologies, e.g., the Internet, virtualization, grid computing, and web services. It is simply the use of computing resources on the Internet instead of on computers. According to Reese (2009), Cloud computing, like the web, is the evolution of a variety of technologies that have come together over the last decade or more to alter an organization's approach to building its information technology (IT) infrastructure and hosting its information systems . Cloud computing program involves computing over a network, where a program or an application may run on many connected computers at the same time.

\section{Review of Literature}

The current study attempts to investigate the impact of Cloud Computing program in improving 
EFL critical reading skills of first year secondary students. There are some related studies that handled the variables of the current study.

Mohammed (2014) investigated the effect of using a Web Quest Model (WM) on general secondary stage students' critical reading performance. The participants were (48) first year general secondary stage students for Girls in Suez Governorate in Egypt. The instruments of the study were pre and post critical reading test. The main results indicated the effectiveness of using the Web Quest in developing General Secondary Stage students' critical reading performance.

Kadir, Subki, Jamal, Ismail (2014) examined the importance of teaching critical reading skill in a Malaysian classroom. In this theoretical paper, the discussion would focus on the importance of reading skills, reading strategies, and metacognitive skills and strategies. These skills and strategies should be given emphasis when teaching reading in schools in order for us to help students develop critical reading skills. It is hoped that at the end of the discussion, we could see the correlation between reading skills, reading strategies, and metacognitive skills and strategies in our objective to develop critical readers among students in schools.

Ammar (2003) investigated the effects of a suggested SRR based program on the prospective EFL teachers' critical reading skills and reading motivation. In this sense, selfregulated reading (SRR) is basically concerned with defining instructional strategies that support students to develop the knowledge and skills required to direct their own reading activities across contexts and time. It subsumes research on cognitive strategies, metacognition and motivation in one coherent construct. The sample of the study involved a cohort of eighty - one third year EFL students at Sohag Faculty of Education, Sohag, Egypt. The Test of Critical Reading and the Reading Motivation Questionnaire designed by the researcher was used as methods of collecting data. Findings of the study indicated that students' self-regulation of their EFL reading resulted in significant gains in their critical reading skills as well as in their motivation to read in English as a foreign language compared to the traditional reading instruction practices.

Chiu (2014) examined the application of a cloud-based, students, teacher, and parent platform in English as a foreign language in Taiwan.This study constructed a cloud-based student, teacher, and parent platform (CSTPP) in collaboration with a Taiwanese textbook publisher. Junior high school students' attitudes to learning English using the developed system were subsequently examined. The study participants were divided into 3 groups: Those in Group A employed the CSTPP with parental participation, those in Group B employed the CSTPP without parental participation, and those in the Control group received traditional lectures. A learning attitude questionnaire was used to assess the students' responses before and after adopting the 3 
learning models. The results of this study indicated that the students who used the CSTPP with parental participation, exhibited altered attitudes toward the teaching methods within 1 month because their assumption that they could only learn from teachers was over turned. After the experiment, a system satisfaction survey was conducted with the students who had used the CSTPP on tablet PSs in classrooms and those who had used the CSTPP on computers at home. Regarding the survey results, both groups of students obtained high scores. In addition, the overall design of the CSTPP was popular among students.

Kravtsov, Gnedkova (2016) determined particularities of using cloud services in English communicative competence forming process and develop the model of distance learning system (DLS) and cloud services interaction that improves the quality of the learning process. Research objectives: to identify, describe and develop methodological features of the model of distance learning system and cloud services interaction; consider on the examples the methods of use cloud services in DLS in foreign language training, aimed at English communicative competence forming process of students; experimentally investigate the level of using of cloud services in distance learning and identify ways of improving its use. Object of research: methodical system of foreign language students' training of language faculties in high institutions. Subject of research: methodological model of the model of distance learning system and cloud services interaction in English communicative competence forming process. Research methods used: review and analysis of scientific publications, psychological, educational and instructional materials, modeling of complex systems, questionnaires, conducting pedagogical experiment. Results of research: The model of distance learning system and cloud services interaction was developed and the methodological particularities of this interaction are defined. Methods of using cloud services on the example of the distance course "Practical English Course Upper Intermediate" describing the methods of doing the tasks in English communicative competence forming process of language faculties were considered. As a result of experiment it was found there is a low level of use of cloud technologies in distance learning is a consequence of a lack of awareness of teachers in the possibilities of its use.

\section{The Pilot study}

In order to substantiate the notion that students lack some basic critical reading skills, a pilot study was undertaken to give more validity to that notion. An EFL critical reading test was administered to the pilot sample that consisted of (27) first year secondary students in Temai Amdid secondary school. The following table illustrates the results of the pilot study: 
Table (1): Results of EFL CRITICAL READING Test (CRT)

\begin{tabular}{|c|c|c|c|c|}
\hline $\begin{array}{c}\text { Critical Reading } \\
\text { Skills }\end{array}$ & Mean Score & S.D. & Percentage & $\begin{array}{l}\text { Maximum } \\
\text { Score }\end{array}$ \\
\hline Identify the main idea & 2.06 & 1.04 & $7.86 \%$ & 4 \\
\hline $\begin{array}{l}\text { Identifying causes and } \\
\text { effect relationships }\end{array}$ & 1.85 & 0.81 & $6.43 \%$ & 4 \\
\hline Drawing conclusion & 2.63 & 1.03 & $7.95 \%$ & 4 \\
\hline Making inferences & 2.86 & 0.96 & $8.94 \%$ & 4 \\
\hline Making comparison & 2.4 & 0.79 & $8.12 \%$ & 4 \\
\hline Total & 11.8 & 4.63 & $55 \%$ & 20 \\
\hline
\end{tabular}

the mean score of the students on the critical reading test was 11.8 . This means that the students need to improve their critical reading skills.

\section{Statement of the problem}

Based on literature review, the researcher's experience and the results of the pilot study, it is evident that secondary school students lack necessary critical reading skills and do not use appropriate strategies to enhance these skills. Consequently, the current study will investigate the effect of utilizing Cloud Computing program to improve critical reading skills.

\section{Questions of the study}

The main question of this study was "How can Cloud Computing program develop the first year secondary school students' EFL critical reading skills?

The main question can be subdivided into the following subquestions:

1. What are the most important

EFL critical reading skills

2. What are the tools of Cloud Computing program that may contribute to improving EFL CR skills of first year secondary students?

3. What is the impact of Cloud Computing program on developing first year secondary students' EFL critical reading skills?

\section{Hypotheses of the study}

The use Cloud Computing program would improve first year secondary' school students critical reading skills.

For reasons of feasibility of data analysis, the following two subhypotheses are posed:

1. There is a statistically significant difference at 0.5 level between the mean scores of the experimental and control groups on the post administration of EFL critical reading skills test in favor of the experimental group. 
2. There is a statistically significant difference at 0.5 level between the mean scores of the experimental group on the pre and post administration of EFL critical reading skills test in favor of the post one.

\section{Delimitation of the study}

\section{The current study will be delimited} to:

1. Sample of Temai Al-Amdid secondary School students.

2. First year secondary stage textbook of the second term.

3. Some cloud computing tools.

\section{Purpose of the Study :}

The current study aimed at:

Identifying the effect of using of Cloud Computing program to develop first year secondary students' EFL critical reading skills.

\section{Design of the study}

This study was a quasiexperimental study that aimed to investigate the effectiveness of using Cloud Computing program in improving critical reading skills for the first year secondary school students.

\begin{tabular}{|c|c|c|c|c|}
\hline \multirow[b]{2}{*}{ Group } & \multicolumn{3}{|c|}{ Main Procedures } & \multirow[b]{2}{*}{$\begin{array}{c}\text { Test/ } \\
\text { Questionnaire }\end{array}$} \\
\hline & $\begin{array}{c}\text { Pre-test } \\
\text { Pre-application }\end{array}$ & Treatment & $\begin{array}{c}\text { Post-test } \\
\text { Post- } \\
\text { application }\end{array}$ & \\
\hline Experimental & $\checkmark$ & $\begin{array}{l}\text { Cloud } \\
\text { Computing } \\
\text { program }\end{array}$ & $\checkmark$ & $\begin{array}{l}\text { Critical Reading } \\
\text { Test (CRT) }\end{array}$ \\
\hline Control & $\checkmark$ & $\begin{array}{c}\text { The regular } \\
\text { teaching } \\
\text { method }\end{array}$ & $\checkmark$ & Questionnaire \\
\hline
\end{tabular}

Figure (1): The quasi-experimental design of the study

\section{Participants}

The participants were 20 first year secondary stage students from Temai Al-Amdid secondary school . The study was conducted to two intact classes where the experimental group was trained according the proposed training program via using Cloud Computing program, while the control group was trained according to the regular method of teaching critical reading skills.

\section{Study Design}

The study adopted the quasi experimental design using a pre-post design with two groups: one experimental and one control to measure the effectiveness of using cloud computing in improving critical reading skills of first year secondary stage students. 


\section{Instruments of the study}

For the purpose of the current study, the following instruments were designed by the researcher:

1. Critical Reading skills Questionnaire (CRSQ) to determine the most important critical reading skills necessary for first year secondary stage students.

2. A pre- post Critical Reading Test (CRT) to measure the effectiveness of using Cloud Computing program in enhancing secondary stage students EFL critical reading skills.

\section{Description of the Critical} reading skills questionnaire

In order to investigate the effectiveness of using a Cloud Computing Program to Develop Critical Reading Skills of EFL Secondary Stage Students, the researcher designed a critical reading skills questionnaire as a tool of the study to identify critical reading subskills required for first year secondary students. The researcher showed the questionnaire to a group of jurors and asked them to read the list and determine the extent to which each sub-skill is relevant to critical reading in terms of its importance and its suitability to the secondary stage students.

Critical reading skills questionnaire validity:

To measure the questionnaire validity, it was submitted to a panel of jury to evaluate it in terms of importance and appropriateness. According to the jury's suggestions, some skills were chosen other skills were deleted.

\section{Internal consistency for the critical reading skills questionnaire}

To measure questionnaire, the researcher administered the test to a sample of students $(\mathrm{N}=27)$ in the first week of the second semester of the academic year 2017-2018. Reliability coefficient was calculated using Pearson correlation coefficient to calculate the correlation between the mean scores of each sub skill and the total score of the questionnaire. The result of Pearson correlation is shown in the following tables.

Table (2 ): Pearson correlation coefficient_for the sub skill 1

(Distinguishing cause and effect relationship).

\begin{tabular}{|c|c|c|c|c|}
\hline Skill1 & $\mathbf{1}$ & $\mathbf{2}$ & $\mathbf{3}$ & $\mathbf{4}$ \\
\hline Pearson Cor. & 0.703 & 0.812 & 0.754 & 0.619 \\
\hline Sig. & 0.01 & 0.01 & 0.01 & 0.01 \\
\hline
\end{tabular}

Table (3): Pearson correlation coefficient for the sub skill 2

(Interpreting the ideas and information implicitly stated in the text).

\begin{tabular}{|c|c|c|c|c|}
\hline Skill2 & $\mathbf{1}$ & $\mathbf{2}$ & $\mathbf{3}$ & $\mathbf{4}$ \\
\hline Pearson Cor. & 0.621 & 0.755 & 0.867 & 0.822 \\
\hline Sig. & 0.01 & 0.01 & 0.01 & 0.01 \\
\hline
\end{tabular}


Table (4): Pearson correlation coefficient for the sub skill 3

(Recognizing the main ideas).

\begin{tabular}{|c|c|c|}
\hline Skill 3 & Skill 1 & Skill2 \\
\hline Pearson Cor. & 0.809 & 0.750 \\
\hline Sig. & 0.01 & 0.01 \\
\hline
\end{tabular}

Table (5): Pearson correlation coefficient for the sub skill 4

(Differentiating between facts and opinions)

\begin{tabular}{|c|c|c|}
\hline Skill 4 & Skill 1 & Skill2 \\
\hline Pearson Cor. & 0.638 & 0.829 \\
\hline Sig. & 0.01 & 0.01 \\
\hline
\end{tabular}

Table (6): Pearson correlation coefficient for the sub skill 5

(Recognizing author's bias)

\begin{tabular}{|c|c|c|}
\hline Skill 5 & Skill 1 & Skill2 \\
\hline Pearson Cor. & 0.834 & 0.810 \\
\hline Sig. & 0.01 & 0.01 \\
\hline
\end{tabular}

Table (7): Pearson correlation coefficient for the sub skill 6

(Differentiating relevant and irrelevant information)

\begin{tabular}{|c|c|c|}
\hline Skill 6 & Skill 1 & Skill2 \\
\hline Pearson Cor. & 0.933 & 0.871 \\
\hline Sig. & 0.01 & 0.01 \\
\hline
\end{tabular}

Table (8): Pearson correlation coefficient for the sub skill 7

(Recognizing author's purpose)

\begin{tabular}{|c|c|c|}
\hline Skill 7 & Skill 1 & Skill2 \\
\hline Pearson Cor. & 0.837 & 0.809 \\
\hline Sig. & 0.01 & 0.01 \\
\hline
\end{tabular}

Table (9): Pearson correlation coefficient for the sub skill 8

(Inferring the antecedent of the sentence.)

\begin{tabular}{|c|c|c|}
\hline Skill 8 & Skill 1 & Skill2 \\
\hline Pearson Cor. & 0.790 & 0.810 \\
\hline Sig. & 0.01 & 0.01 \\
\hline
\end{tabular}

Table (10): Pearson correlations coefficient

(for the all sub skills and the total score)

\begin{tabular}{|c|c|c|c|c|c|c|c|c|}
\hline Total Skills & Skill 1 & Skill 2 & Skill 3 & Skill 4 & Skill5 & Skill6 & Skill7 & Skill8 \\
\hline Pearson Cor. & 0.872 & 0.898 & 0.646 & 0.729 & 0.816 & 0.792 & 0.842 & 0.880 \\
\hline Sig. & 0.01 & 0.01 & 0.01 & 0.01 & 0.01 & 0.01 & 0.01 & 0.01 \\
\hline
\end{tabular}

From the results of tables ( 2- which means that the questionnaire is

$10)$, it is clear that Pearson

Correlation Coefficient for the sub internally consistent(valid).

skills of the questionnaire was 0.882

A pre- post Critical reading test:

To measure the effectiveness of using cloud computing program in 
enhancing EFL secondary stage students' critical reading skills.

\section{Description of the critical reading test}

A pre- post critical reading test consisted of two passages designed to measure critical reading skills with regard to distinguishing cause and effect relationship, interpreting the ideas and information, implicitly stated in the text, recognizing the main ideas, differentiating between facts and opinions, recognizing authors' purpose and inferring the antecedent of the sentence. The researcher gave each pupil a separate mark for each sub skill. These separate marks are then added to calculate the overall score of the critical reading test. The total score of the critical reading test was twenty.

\section{Validity of the critical reading test}

The critical reading test was validated by a group of jurors to check the test according to suitability to the students' level, and effectiveness in assessing students' achievement. The researcher asked jurors to provide modification and give any suggestions and recommendations. The researcher analyzed the jurors' responses and took their suggestions into consideration, then the researcher modified the checklist in its final form.

\section{Reliability of the critical reading} test

The researcher used Alpha coefficients for the test. Table 11 describes the results of alpha coefficient of the test as a whole and for each sub skill.

Table 11: Cronbach Alpha coefficient for the critical reading test

\begin{tabular}{|c|c|c|c|c|c|c|c|c|c|}
\hline Skills & Skill 1 & Skill 2 & Skill 3 & Skill 4 & Skill5 & Skill6 & Skill7 & Skill8 & Total \\
\hline $\begin{array}{c}\text { Alpha } \\
\text { Cronbach }\end{array}$ & 0.698 & 0.771 & 0.540 & 0.709 & 0.562 & 0.755 & 0.624 & 0.789 & 0.882 \\
\hline Sig. & 0.01 & 0.01 & 0.01 & 0.01 & 0.01 & 0.01 & 0.01 & 0.01 & 0.01 \\
\hline
\end{tabular}

Based on the results in Table 11, it was concluded that the test is reliable.

\section{Pre experiment}

To make sure that the students participated in the experimental group and the control groups were almost equal in their level of critical reading skills (distinguishing cause and effect relationship, interpreting the ideas and information, implicitly stated in the text, recognizing the main ideas, differentiating between facts and opinions , recognizing authors' purpose and inferring the antecedent of the sentence) before the experiment, the researcher administrated the critical reading test to both the experimental and the control groups. In addition, the researcher used $t$. test for calculating the differences between the mean scores of the experimental group and the control group on the critical reading test. The results were shown in the following table. 
Table (12): Difference between the mean score of the experimental group and the control group on the pre-administration of the critical reading test

\begin{tabular}{|c|c|c|c|c|c|c|}
\hline \multirow{2}{*}{ Skills } & \multicolumn{2}{|c|}{$\begin{array}{c}\text { experimental group } \\
\mathbf{n}=\mathbf{2 0}\end{array}$} & \multicolumn{2}{c|}{$\begin{array}{c}\text { control group } \\
\mathbf{n = 2 0}\end{array}$} & \multirow{2}{*}{ T-value } & \multirow{2}{*}{ Sign. } \\
\cline { 2 - 5 } & Mean & Std. Devi. & mean & Std. Devi. & & \\
\hline Skill 1 & 2.40 & 1.18 & 2.3 & 1.30 & 0.24 & No Sig. \\
\hline Skill 2 & 2.25 & 1.21 & 2.0 & 1.07 & 0.69 & No Sig. \\
\hline Skill3 & 0.95 & 0.75 & 1.20 & 0.76 & 1.03 & No Sig. \\
\hline Skill 4 & 1.15 & 0.81 & 1.10 & 0.91 & 0.18 & No Sig. \\
\hline Skill 5 & 0.95 & 0.61 & 1.10 & 0.45 & 0.89 & No Sig. \\
\hline Skill 6 & 1.10 & 0.78 & 1.20 & 0.89 & 0.37 & No Sig. \\
\hline Skill 7 & 1.00 & 0.73 & 1.25 & 0.64 & 1.15 & No Sig. \\
\hline Skill 8 & 1.10 & 0.64 & 1.20 & 0.62 & 0.50 & No Sig. \\
\hline Total Skills & 10.90 & 3.02 & 11.35 & 2.05 & 0.55 & No Sig. \\
\hline
\end{tabular}

indicated that there are no significant differences between the mean scores of the experimental and the control groups on the pre administration of the critical reading test. It was noticed from the results in the table above that the two groups were almost equivalent

\section{Discussion of results}

Results illustrated above revealed that there is an obvious improvement in the experimental group students' critical reading skills on the post administration of the critical reading test. This significant improvement is due to implementing the cloud

\section{- Verifying the first hypothesis}

The first hypothesis stated that: There is a statistically significant difference at 0.05 level between the mean score of the experimental and control groups on the post administration of the critical reading skills test favor of the experimental group. T-test was used to test the first hypothesis which addressed the differences between the experimental group and the control group on the post administration of the critical reading test. Table (13) shows the results. 
Table (13):Difference between the mean score of the experimental group and the control group on the post-administration of the critical reading skills test

\begin{tabular}{|c|c|c|c|c|c|c|}
\hline \multirow{2}{*}{ Skills } & \multicolumn{2}{|c|}{$\begin{array}{c}\text { Experimental } \\
\text { group }\end{array}$} & \multicolumn{2}{c|}{$\begin{array}{c}\text { Control } \\
\text { group }\end{array}$} & \multirow{2}{*}{ t-value } & \multirow{2}{*}{ Sig. } \\
\cline { 2 - 5 } & $\mathrm{M}$ & Std. S.D. & $\mathrm{M}$ & Std. S.D. & & \\
\hline Skill 1 & 2.65 & 1.22 & 2.40 & 1.04 & 9.02 & 0.01 \\
\hline Skill 2 & 6.00 & 1.12 & 2.45 & 1.23 & 9.51 & 0.01 \\
\hline Skill3 & 2.70 & 0.80 & 1.40 & 0.75 & 5.28 & 0.01 \\
\hline Skill 4 & 2.65 & 0.67 & 1.30 & 0.80 & 5.77 & 0.01 \\
\hline Skill 5 & 3.00 & 0.79 & 1.35 & 0.67 & 7.09 & 0.01 \\
\hline Skill 6 & 2.60 & 0.75 & 1.10 & 0.71 & 6.44 & 0.01 \\
\hline Skill 7 & 2.75 & 0.91 & 1.00 & 0.56 & 7.31 & 0.01 \\
\hline Skill 8 & 3.00 & 0.73 & 1.30 & 0.65 & 7.76 & 0.01 \\
\hline Total Skills & 28.35 & 3.56 & 12.30 & 2.59 & 16.29 & 0.01 \\
\hline
\end{tabular}

Results in table (13 ) indicate that the mean score of the students of each critical reading sub-skill in the experimental post-test was higher than the mean score of the control group. It shows that the pupils mean score in the overall critical reading test of the experimental group was (28.35) and the control group overall score of the post-test was (12.30). These results illustrate that the estimated $t$-value is significant at 0.01 levels. This reflects that there are statistically significant differences between the mean scores of the control and experimental group on the post-administration of critical the reading test in each skill and in the total score. These significant differences are in favor of the experimental.

\section{- Verifying \\ the second hypothesis}

The second hypothesis stated that: There is a statistically significant difference at 0.01 levels between mean score of the experimental group on the pre and post critical reading skills test in favor of the post one. Ttest was used to compare the difference between the mean score of the experimental group students in the critical reading test before and after administering the cloud computing program and to determine the effect of the program on critical reading subskills of the experimental group. The following table shows the results. 
Table (14) Difference between the mean score of the experimental group students on the pre and Post-administration of the critical reading skills test

\begin{tabular}{|c|c|c|c|c|c|c|c|}
\hline \multirow{2}{*}{ Skills } & \multicolumn{2}{|c|}{$\begin{array}{c}\text { Experimental } \\
\text { group Pre }\end{array}$} & \multicolumn{2}{|c|}{$\begin{array}{c}\text { Experimental } \\
\text { group Post }\end{array}$} & \multirow{2}{*}{ T-value } & \multirow{2}{*}{ Sign. } & \multirow{2}{*}{ Eta } \\
\cline { 2 - 5 } & Mean & Std. Devi. & Mean & Std. Devi. & & & \\
\hline Skill 1 & 2.40 & 1.18 & 2.65 & 1.22 & 9.80 & 0.01 & 0.83 \\
\hline Skill 2 & 2.25 & 1.21 & 6.00 & 1.12 & 9.45 & 0.01 & 0.82 \\
\hline Skill3 & 0.95 & 0.75 & 2.70 & 0.80 & 6.47 & 0.01 & 0.68 \\
\hline Skill 4 & 1.15 & 0.81 & 2.65 & 0.67 & 8.11 & 0.01 & 0.77 \\
\hline Skill 5 & 0.95 & 0.61 & 3.00 & 0.79 & 8.34 & 0.01 & 0.78 \\
\hline Skill 6 & 1.10 & 0.78 & 2.60 & 0.75 & 5.09 & 0.01 & 0.57 \\
\hline Skill 7 & 1.00 & 0.73 & 2.75 & 0.91 & 7.67 & 0.01 & 0.75 \\
\hline Skill 8 & 1.10 & 0.64 & 3.00 & 0.73 & 8.32 & 0.01 & 0.78 \\
\hline Total Skills & 10.90 & 3.02 & 28.35 & 3.56 & 16.27 & 0.01 & 0.93 \\
\hline
\end{tabular}

T-test for was used to compare the mean scores of the experimental group on the pre and post administration of the critical reading test. Table (14) shows that the mean scores of the experimental group students' post application in the each critical reading sub skills and in the total scores were higher than the pre administration. This illustrates also that the estimated t-value is significant at 0.01 levels. This indicates that t-test results were significant at 0.01 levels which reflect the significant differences between the mean scores of the experimental group pre and post-test favoring the post-application. Therefore, the cloud computing program was effective in improving each critical reading sub-skill.

Table (14) also illustrates the effect size of the application of the cloud computing program on the improvement of critical reading skills of the experimental group students in each critical reading skills under investigation. Results indicated that the effect size is high in the each sub skills and the total score. The eta square values are $(0.83,0.82,0.68,0.77,0.78$, $0.57, \quad 0.75, \quad 0.78, \quad 0.93)$. These differences foster the positive effect of the program on students' critical reading achievement. Therefore, the hypotheses of the study are proved and accepted.

\section{Discussion of results}

In this part, results of the present study are discussed in terms of the following critical reading skills (distinguishing cause and effect relationship, interpreting the ideas and information, implicitly stated in the text, recognizing the main ideas, differentiating between facts and opinions, recognizing authors' purpose and inferring the antecedent of the sentence). Results illustrated above revealed that there is an obvious improvement in the experimental group students' critical reading skills 
on the post administration of the critical reading test. This significant improvement is due to applying the cloud computing program to the experimental group.

The t. Test has shown that there were significant differences between the post test scores of the control group and the experimental group at 0.01 levels in favor of the experimental group. This means that the experimental group showed significant improvement in their critical reading skills.

It can be concluded that cloud computing program was effective in improving critical reading skills. Experimental group students appeared a great degree of positive attitudes, motivation, interests towards the administration of the program. During the administration of the program, students were very interested, active and engaged in cloud computing.

Despite of these positive effects of cloud computing, there were few challenges of applying the program such as the lack of net connection on the school. To solve this problem, the researcher bring CD rooms, flash net and ask students to put their answers on it and download it offline . the second problem that face the researcher during the application was the limitation of numbers of computers on the school. The researcher solved this problem by bringing some extra computers for all students so they can engage effectively.
It is clear from the discussion so far, that the cloud computing program was useful in developing students' critical reading skills. These findings agree with those finding of other researcher in the field. For instance, Sadeghi \& Soltanian (2010) indicated similar findings where they found that computerized reading contributes to the development of EFL reading skills more than the conventional academic reading methods. Such findings confirm the findings of Fawzy (2017) where a finding revealed that the experimental group outperformed the control group in the subtest of critical reading test. The experimental group achieved more progress than the control one on overall critical reading test scores.

Based on the above analysis of the data, it can be concluded that the cloud computing was effective in developing some critical reading skills of EFL secondary stage students. The next chapter will deal with drawing conclusions, providing recommendations and suggestions for further researchers.

\section{Conclusion:}

The present study provided evidence for the effectiveness of using a cloud computing program for developing EFL critical reading skills of secondary stage students.

\section{Recommendations}

Based on the results of the present study, the following recommendations can be provided:

1. The critical reading skill should receive appropriate attention in order to be 
developed especially at secondary and preparatory stages.

2. Decision makers at the Ministry of Education should adapt cloud computing tools in the teacher's guide to be applied by teachers in reading lessons.

3. The Faculties of Education should train the pre-service teachers in using the new trends of teaching such as cloud computing.

\section{Suggestions for Further Research}

Based on the findings of the current study, the following areas for future research were suggested:

1. Using cloud computing in developing other language skills. (writing, listening and speaking).

2. Conducting other studies in order to investigate whether cloud computing based program has the same influence on other reading skills specially comprehension, fluency)..

\section{References}

Ammar,A(2003). The Effects of Self Regulated Reading Strategy Development on the Prospective Efl Teachers' Critical Reading Skills and Reading Motivation:(Thesis,Sohag Faculty of Education).
Chiu, F. Y. (2014). The Application of a Cloud-Based Student, Teacher, and Parent Platform in English as a Foreign Language Education. Turkish Online Journal of Educational Technology-TOJET, 13(3), 178187.

Chiu, F. Y. (2014). The Application of a Cloud-Based Student, Teacher, and Parent Platform in English as a Foreign Language Education. Turkish Online Journal of Educational Technology-TOJET, 13(3), 178187.

College of the Canyons (2012). Skills 4 Success: Supplemental Learning Workbook. Retrieved October 7, 2012, from http//www.canyons.edu.

G. Reese, "Cloud application architecture," (1st ed.), O'Reilly, 2009.

Kathleen J. \& Nikki A. (2016) Critical Reading Strategy. Retrieved Oct. 30, 2016, from Salisbury university web site: https://goo.gl/C1QZYY.

Kravtsov, H., \& Gnedkova, O. (2016). The Use of Cloud Services for Learning Foreign Language. ICT in Education, Research and Industrial Applications.

Mohammed ‘M .(2014)."The Effect of a WebQuest Strategies on Achievement and Retention in Developing Critical Reading Skills". Lecturer at Curriculum \& Instruction Dept, Faculty of Education, Suez University.Egypt. 
Norbaiyah Abd Kadir, Roose N Subki , Farah Haneem Ahmad Jamal and Juhaida Ismail (2014) . The Importance of Teaching Critical Reading Skills in a Malaysian Reading Classroom. University Technology MARA (UiTM) Pahang, Malaysia.
Pirozzi, R. 2003. Critical Reading, Critical Thinking (2nd ed.). New York: Longman.

Rings, T., Caryer, G., Gallop, J., Grabowski, J., Kovacikova, T., Schulz, S., \& Stokes-Rees, I. (2009). Grid and cloud computing: opportunities for integration with the next generation network. Journal of Grid Computing, 7(3), 375. 